\title{
Walking on the Pages of the Word of God
}

For many Evangelicals, the State of Israel has come to occupy a central place in the imagination and articulation of Christian faith and practice. Israel is admired for its "miraculous" historical achievements, embraced as a fulfillment of biblical prophecies, cherished for its particular proximity to God, and defended with much fervor in political and theological debates. These sentiments are also frequently translated into religious practices: tours and pilgrimages to Israel; celebrations of Jewish holidays; intercessory prayers for the "peace of Jerusalem"; political lobbying; financial contributions to Israeli society; and volunteer work in Israel in order to be a blessing to the Jewish people. All of these activities point to an extended and profound religious interest in the State of Israel that shows no sign of waning in the near future.

Protestant Christians, who had long speculated about—and sometimes also worked towards - the national restoration of the Jews, embraced the new-born state in 1948 and were hugely enthused by its territorial expansion following the ' 67 war. For many Evangelicals, these events signaled the fulfillment of biblical prophecies: when the people of Israel returned to a homeland that had been "trampled on by the gentiles" (Lk. 21:24) for near two thousand years, it provided affirmation that history was moving towards its fulfillment and, furthermore, that the Bible was a reliable source for the interpretation of the present. That the State of Israel became a sign of the times, however, also made it fundamentally different from any other political construct: it left Israel shimmering in an other-worldly light. For many Evangelicals Israel became an index of divine intent, a meta-historical, semi-spiritual entity by virtue of which one could not only gain insight into, but also interact with divine realities.

The Six-Day War in ' 67 was followed by great prophetic excitement. In Jerusalem, expat Evangelicals formed a variety of networks during the '7os which eventually led to the founding of three Christian Zionist ministries: the Bridges for Peace; the International Christian Embassy; and Christian Friends of Israel. These ministries were developed to serve as a bridge between the State of Israel and the Evangelical world; to educate Christians about Israel; and to "comfort the Jewish people" by practical means. While initially not as broadly representative as they often claimed to be, more than three decennia of socio-political navigation within Israeli society has eventually established them as central players in what they themselves perceive as a global—and eschatologically 
significant-Christian movement that is aligning with God's chosen people prior to the conclusion of the eschatological drama. Joining this movement, for instance as a volunteer, means becoming involved in the meta-historical redemptive process.

I have in this work approached Christian Zionism primarily as a discursive process that is concerned with the ongoing production of connections between the State of Israel, its formative ideology, and Christian sacred history. In the analytic section (Chapters Three, Four, and Five) I examined this process within three broad discursive domains: talk about the religious self, about the land of Israel, and about the biblical text. While analytically separated in this work, I have consistently argued that the religious significance of the State of Israel emerges primarily from the interactions between these three domains.

Chapter Three focused on the religious self and described how Evangelical coming-to-Israel stories are articulated in relation to two classical Christian narrative genres: the calling narrative and the conversion narrative. Among the Evangelicals in Jerusalem, the transformative experience of "realizing Israel's spiritual significance" is embedded in Evangelical narrative forms that emphasize the dialectics between divine and human agency and the authentic knowledge of "the heart". Through these narratives, Zionism comes not only to have a personal religious value but, in the process, also recalibrates Evangelical symbolic systems into a partly new articulation of Evangelical faith. Understanding and supporting the State of Israel becomes an important part of what it means to be a born-again Christian. Among the volunteers, the sometimes ritual-like performance of these narratives situates the encounter with Israel as a religious conversion process.

Chapter Four explored how the experience of Israel has reawakened previously slumbering religious traditions concerning sacred space. In the volunteers' narratives Israel is discursively produced as a special place with a unique capacity to mediate divine presence. While such traditions have never been entirely absent from Protestant Christianity, they have frequently been theologically rejected and subjected to polemic, particularly by Protestants who understand materiality as a problem for authentic experience of the divine. The discursive practices of the volunteers showed how the notion of sacred space is finding new currency in Evangelical Zionism but also how these reawakened narratives, myths, and symbols need to be negotiated both in relation to the encounter with the empirical realities of the place, and Protestant ideas about religious fetishism.

The final analytical chapter focused on "biblical literalism" as the textual ideology of the Evangelicals in Jerusalem. It was argued that while "biblical literalism" has often been understood as the cause for Evangelical 
Zionist views of the state of Israel — both among volunteers and academic observers-it also needs to be understood as an outcome of Evangelical engagement with Israel. Bible prophecy in its retrospective form and discourses concerning the "Hebraic roots of Christian faith" are deeply embedded in arguments about biblical authenticity and the legitimacy of Evangelical religious forms. While the former often serves as empirical evidence for the truth of the biblical scripture, the latter constructs a historical narrative within which Evangelical Zionism is situated as a rediscovery of authentic biblical religion. In addition, the same narrative construes ideological opponents as descendants of Greek symbolic manipulation and man-made traditions that lead them into the theological quagmires of allegory, replacement theology, and anti-Semitism.

By its substantial discursive and practical engagement with a modern state, Christian Zionism significantly de-stabilizes the boundaries between religion and politics as they have traditionally been imagined within secularized societies. Since the late '6os, Evangelicals in Jerusalem have negotiated these boundaries by engaging in a range of activities that have often been construed by observers as inappropriately political. The organizations, as well as the volunteers in Jerusalem, however, consistently—and more or less univocally - prefer to construct their identities along apolitical religious lines and often deny political interests and motivations. In their view, their activities are based on a biblical mandate and they are simply friends of God's chosen people who are trying to heal the wounds of the past. Yet, as much as it would be a mistake to treat Evangelical engagements with Israel merely as political expressions of conservative religious beliefs, it would also be flawed to turn a blind eye to how thoroughly embedded these religious discourses are in ideological concerns. I have tried to balance these perspectives here because I find that interpreting them as one or the other would only serve to reinscribe boundaries that privilege particular narratives about the legitimacy of these expressions. However, I also believe that the analysis has shown how porous these boundaries are. I have emphasized how ideological and political constructs enter Evangelical religion as religious symbols; in other words, as something that significantly contributes to, and clarifies what it means to be a born-again Christian. The analysis has been geared towards the religious significance attributed to the State of Israel in these discourse; a significance which, as we have seen, is both profound and wide-ranging in terms of the religious identities of the volunteers. Before closing this work I would like to return to some of the questions that were raised in the introductory chapter and finally to turn to some areas that I believe will be important for future academic explorations of Evangelical Zionism. 


\section{Continuities and Discontinuities of Evangelical Zionism}

In the first chapter of this book I identified the continuities and discontinuities between Christian Zionism and Evangelicalism more broadly as the main theoretical focus of this project. I was (and still am) interested in the ways in which Evangelicals negotiate the place of the State of Israel in their personal faith, and in relation to the Bible, to theological tradition, and to the empirical experience of living and working in Israel. In all these areas, the exploration has shown a Christian movement which emerges from Evangelical ways of being in the world, but that is also structured by ancient Christian ways of perceiving the Jew/Israel as a signifier of divine intent (Haynes 1995). The Evangelicals in Jerusalem place high value on personal and intimate relationships with God (Bielo 2008, Luhrmann 2004, Moberg 2013), draw on well-established Christian speech genres in order to articulate their journeys to Israel (Stromberg 1993, Williams 2013), engage with the Bible in a radically personalized way which is primarily focused on presence and relevance (Bialecki 2009, Malley 2004), continuously search for traces of divine agency in the world and in their own lives (Harding 2000), and generally understand themselves as Evangelicals in terms of belonging, beliefs, and practices. In all these areas, the volunteers, perhaps unsurprisingly, are in fundamental continuity with more general Evangelical religious forms.

However, I have also continuously stressed how the ministries and the volunteers in Jerusalem perceive themselves as part of a global movement that is set on reforming Christian faith and practice. These reform ambitions are visible in several areas but perhaps most in the ongoing discursive contestations surrounding the religious meaning of Israel: narratives about the Hebraic roots of faith; questions about biblical authenticity and fetishism; and the focus on the transformative encounter with Israel and its accompanying hermeneutical changes.

The analysis has also shown that these ambitions are more than mere talk: by introducing Zionism and the State of Israel as religious concepts some central Christian questions receive partly new answers: How does God make Himself known in the world? How can one rely on the biblical message? What is authentic Christian belief and practice? What problems, if any, does materiality pose for religious experience? In the discourses described in this work the State of Israel is deeply embedded in the answers to all these questions. Whether approached from an historical, theological, or anthropological perspective, these are significant changes that need to be considered not only on a superficial but also on a structural level; rather than simply adding new elements to Evangelical faith they propel a (partial) restructuring of the religious system 
and a re-evaluation of core theological, hermeneutical, and semiotic questions. Some of these questions have been addressed in the preceding chapters but many also remain to be considered in future explorations of Christian Zionism. In the hope of contributing to the ongoing academic discussion about contemporary Evangelicalism I will draw attention in the following to three areas which I believe will be particularly fruitful.

\section{Globalizing Christian Zionism}

To date, scholarly research and media representations of Christian Zionism have overwhelmingly focused on the North American ecclesiastical, political, and cultural context, sometimes to the extent that the trajectories along which Christian Zionism has developed in North America have also been taken as paradigmatic of its development elsewhere. However, while Evangelical forms of Zionism lately seem to have lost some of their momentum in European and North American contexts, Evangelical and Charismatic Christianity in the Global South is becoming an increasingly important field of interaction between Zionism and Christianity (Pew Research Forum, 2011). How that relationship will develop in future years will in no small part depend upon the activities of the Christian ministries in Jerusalem: how able they are to tap the potential of the Global South and include Southern voices in their articulation of faith; and how they fare in the discursive contestations that have surrounded the State of Israel since the late '6os. As the comments from David Parsons in Chapter Five testify, this is a development of which the ministries in Jerusalem are highly aware, and something which they consider to be both politically and eschatologically significant.

In spite of the growth of these ideas in various Christian contexts, this development has seen little extended research so far, although there are a few exceptions (Clatterbuck 2014, Gifford 2001, 2003, 2009, Girard 2014, Helgesson 2006, Kalu 2008). This oversight becomes even more visible by comparing it to another phenomenon within Southern Pentecostal and Charismatic churches which has received an enormous amount of scholarly attention in recent years: the "prosperity gospel" and its connection to various local understandings of society, economics, agency, morality, health, and the body (Attanasi and Yong 2012, Gifford 2004, Haynes 2012, Heuser 2015, Meyer 2002). As with prosperity preaching in Pentecostal churches, it is likely that Christian Zionism in the South is affected by both global and local factors: local theologies, ethnic genealogies, narrative traditions, Bible reading practices, missionary histories, and the globalization of Evangelical media. It is also likely that Christian Zionism, like the prosperity gospel, connects with various understandings of society, economics and politics but also that it contributes to reshape these 
understandings when introduced in a new context. Yet, so far, very little about these processes is known: how Christian Zionism globalizes; its paths of circulation; and the ways in which it localizes in different contexts and communities. While it is, of course, very difficult to estimate with any precision either the size or the global reach of the phenomenon-not to mention the heterogeneous movement that is crystallizing around these ideas-the information that does exist points to a Christian interest in Israel that far outweighs the paucity of research that exists on the topic.

An added benefit of research into Christian Zionism in non-European/nonNorth American contexts would be the possibility of comparing the trajectories along which it develops, and to test interpretations of it that are available in research to date, including those in this study. As already pointed out, existing research has stressed theological trends such as premillennial dispensationalism (Weber 2004), ("literalist") bible reading practices (Ariel 2002, Spector 2009), and, more recently, the connection to national or communal identities (Smith 2013, Stewart 2015). How well would those interpretations hold water when applied to Zionist Pentecostals or Charismatics in Brazil, Nigeria, South Korea, or South Africa? In what ways would they challenge or support existing theories about the phenomenon? While cross-cultural comparison is difficult, and perhaps should be embarked upon with some caution, it would also provide interesting questions of benefit to the field. If Christian Zionism is approached less as a fixed belief tradition and more as a "cross-contextually recognizable system of symbolic associations" (Engberg and Stewart 2014) — between biblical Israelites and modern day Israelis, between biblical Israel and the State of Israel, and between historical events and eschatological narratives - such comparisons might not only be feasible, but highly beneficial to the understanding of the phenomenon as a whole.

\section{Contesting Language Ideologies}

In Beyond Logos (2011), Jon Bialecki and Eric Hoenes del Pinal develop an argument for an expanded study of Christian language ideologies as competing, contrasting, and contested. As I noted in Chapter One, they argued that, although Christian language has been studied in many different contexts, the general picture of Christian — particularly Protestant — language has been surprisingly uniform: centering around the sincere speaking subject, and privileging interiority, intimacy, and intentionality as an ethics of speech $(2011,580)$. While several authors have recognized the reality of competing language ideologies, these contestations have often been analyzed in missionary contexts where a pre-Christian language ideology has been contrasted against ideological stances arriving with the missionaries (e.g. Keane 2007, Robbins 2001). The 
emergence of new language practices in these accounts has often been understood to be derived from a modern Christian culture fundamentally shaped by Western Protestantism.

In comparison, this exploration of contemporary Evangelical Zionism has shown a language ideology which emerges from, and also contrasts with other Protestant understandings of what language is, and what it is supposed to do. Furthermore, the emergence of new language practices in Jerusalem is not the result of external forces but rather of the Evangelicals' own mobility - which has brought them to this new geographical context - and their attempts to harmonize this experience with already existing Evangelical language. This example raises questions about the flexibility and adaptability of Protestant speech, as well as about the possibilities for human subjects to shape and re-shape their communities' language ideologies to meet the needs of the present. In the examples presented herein, what can, and cannot, be said is being negotiated in relation to both theological tradition and the context within which the subjects currently reside. To what extent do these results reflect more general aspects of how Christian language works, and in what aspects, if any, are they unique?

Further research, both into Christian Zionism and into other Evangelical contexts would be needed to shed more light on how general these observations are but I believe a few things might already be said with confidence. First, while the State of Israel, as I have argued, can be understood as a sign that mediates divine presence, it is also a constantly evolving social and political formation. Such a situation, as discussed in Chapter Four, forces the volunteers to adapt their language to contextual circumstances and situations to an extent which possibly would not have been necessary in other contexts where this duality does not exist to the same degree. A second aspect which is peculiar to Evangelical Zionism is the inevitably unique role that the land and people of Israel has in the Bible and in Christian theological traditions. For a Biblicist community, this implies that talk about Israel is always partly structured in advance by the Bible, and that theological traditions already in place need to be addressed, negotiated, and discussed. I have here emphasized the formative role of these sources and contestations for the volunteers' talk about Israel.

Studying Christian language ideologies as competing, contrasting, and contested (Bialecki and Hoenes del Pinal 2011) implies the acknowledgment that concrete language practices change with social and cultural circumstances; that the very contestations can be influential in shaping said speech; and that even communities which are deeply wedded to the authority of the biblical text and/or theological dogmas can nevertheless prove highly flexible in practice. More studies in that direction would greatly increase our understanding 
of religious language and the ways in which it shapes and reshapes religious identities.

\section{Alternative Readings of Israel}

The symbolic role of the State of Israel in Christian imaginaries has in this work been explored through a deliberately one-sided perspective: that of Zionist evangelicals in Jerusalem. At an early stage in my research I was interested in doing a comparative project with Christians from both sides of the political fence; however, I ultimately decided against that due to practical limitations, and the amount of time in the field that would require. Yet, using the perspective taken towards Christian Zionism in this book, a similar project exploring the symbolic role of Israel for Christians who are critical of the State and/or who do not view it as the fulfillment of biblical prophecies, would not only be highly interesting but also contribute to the more general understanding of Israel's symbolic role. In such a context, similar questions to those I have asked here would apply: How is biblical and theological authenticity created and maintained? How does the encounter with land shape political, moral, and religious identities? What sort of language practices are being used to legitimize political and religious activity — and how similar are they to those explored in this work? Are there similar conversion stories being told among pro-Palestinian Christians? While Christian pro-Palestinian activism has historically mainly relied on more liberal theological platforms, the Christ at the Checkpoint Conference organized every second year by Bethlehem Bible College shows that there is also an increasing identification with Palestinian narratives in the Evangelical camp. Additionally, just as there are biblical prophecy tours to Israel, there are organized trips that focus on Palestinian Christian links to the land, and their situation under military occupation (Feldman 2011, Kaell 2014). Considering the role of the State of Israel in Christian contestations about authenticity, fetishism, and materiality, including these Christian communities in future research would contribute to a more solid understanding about how that role is being put to use in the construction of Christian identities.

\section{Walking on the Pages}

Five years ago, I started this research project eager to try to understand why the State of Israel evoked such strong emotion among many Evangelical Christians. Was their support the result of (mis-)interpretations of biblical prophecies, as considerable previous research had suggested? Was it a consequence of 
the cultural influence of dispensationalism and biblical literalism? Or was the religious language merely a chimera obscuring the real motivations: conservative political beliefs and support for the military alliance between Israel and the U.S.? Now, some years later, I believe all of these explanations are relevant, but that none of them really goes to the heart of the matter. Evangelicals, at least the volunteers in Jerusalem, embrace Zionism simply because they feel that it is what God asks them to do. In their experience, this embrace brings them closer to God, and to the plan that He has for their individual lives. They struggle with how to understand it, with the ways in which it resonates with their Evangelical faith, but in the end what really matters, as with most Evangelicals, is their personal relationship with God.

It has been argued that Christian intimacy with God is created through an ideological rejection of the material (Keane 2007). Considering the narratives in this work, that perspective seems, if not wrong, at least misleading. Among the volunteers, intimacy with God is not constructed through such a rejection but rather in a negotiation with Israel as a historical and material reality. The individual's walk with God is centered on engagement with Israel; the realization of Israel's spiritual significance is articulated as the discovery of a new, more religious self; and the land of Israel is understood as a sacred space that has a unique capability to mediate divine presence. In all these cases the land and State of Israel emerge as a route to cultivating intimacy with God. It is not an unproblematic way to construct such intimacy, and it is not final but, judging from their stories, it works, and it is deeply spiritually fulfilling.

There are people that are tremendously spiritual, like they spiritualize absolutely everything — I'm not sure if you understand what I mean? And yet, here [in Israel], it's just more real. I don't consider that those were Bible times [before]; I consider that we're in Bible times [now] and that we're literally walking on the pages of the Word of God. (my emphases)

When Karen tells me this, it is spring 2013 and we are sitting in an ordinary office in a Christian-run food bank on the outskirts of Jerusalem. There is nothing about the office that particularly catches the eye; it is small, a bit cramped with books, files, and folders; the sun is shining in through one of the windows. Where Karen "literally" walks is on the hard concrete floor of the food bank: between the office, the shelves with their food products, and the pallets that are sent to different locations in Israel and in the territories on a daily basis. Sometimes she also helps register newly arrived Jewish immigrants who are in need of help: her favorite part of the volunteer work, she says. 
Insofar as I can tell, Karen is entirely sincere when she tells me where she walks, and how she understands it. Yet the conflation between biblical and contemporary times is puzzling. Her statement not only collapses the biblical past and the eschatological future into an expanding present but also, crucially, juxtaposes the biblical text with a contemporary state. In spite of her comment about the people who "spiritualize absolutely everything", to me, it seems like an immensely spiritual thing to do. Perhaps, however, it is this very juxtaposition that is responsible for the deeply felt intimacy with God. Embedded in the Word, Karen experiences how her faith has become more "solidified", more "real", she says. In a sense it is easy to imagine why: she is walking on it. 